\title{
The Effect of Product Knowledge, Perceive of Fullness and Promotion to Intention to Use Electronic Money Server Based
}

\author{
Muhammad Arifiyanto ${ }^{1}$, Nur Kholidah ${ }^{2}$ \\ \{manajemen.arifiyanto@umpp.ac.id $\left.{ }^{1}\right\}$ \\ Department of Management, University of Muhammadiyah Pekajangan Pekalongan, Indonesia ${ }^{1}$ \\ Department of Economic Sharia, University of Muhammadiyah Pekajangan Pekalongan, Indonesia ${ }^{2}$
}

\begin{abstract}
Money has developed rapidly over time as payment tools. The development of money is also influenced by the development of electronic money generating information technology. The volume of transactions and the value of electronic money have recently increased as customer demands for payment tools have increased. Many factors affect the desire of consumers to use electronic money. The objective of the study is to analyze the effect of product knowledge and promotion on the purpose of using an electronic moneybased server. This study was conducted at Muhammadiyah Pekajangan Pekalongan Faculty of Economics and Business University, where a total sample of 183 people were taken using a targeted sampling method. Using analysis data, data processing includes validity tests, trustworthiness tests, normality tests, multicollinearity tests, heteroscedasticity tests, linear regression tests, F-tests, t-tests, and determination coefficients. The results of this study showed that all variables are positive. The usefulness has the greatest influence on purpose as the coefficient of regression is 0.722 . and the product knowledge has a coefficient of regression 0.204 .
\end{abstract}

Keywords: Server based electronic money, intention to use, product knowledge, perceived usefulness

\section{Introduction}

Information technology is a technology used to process data to create quality information, specifically relevant, accurate and up-to-date information for personal, business and government use in a variety of ways.

Informatics is growing rapidly today. The development of information technology can improve performance and allow various activities to be implemented quickly so that productivity is increased and a new way of life is encouraged. The effects of the development of IT are evident in several fields, including the payment system, especially the retail payment system known as electronic money (e-money).

Electronic money according to the Indonesian Bank regulation [1] is a payment tool issued on the basis of the amount of money that was deposited with the issuer in advance, and the amount of money that was electronically stored on a media server or chip. Since its launch in 2007, the use of electronic money has continued to grow in Indonesia. This can be seen from the number of transactions, the amount of money in circulation and the number of electronic 
money organizers (www.bi.go.id). In terms of the number of users also experienced per plants reached $77.6 \%$ [2].

One way to expand the use of electronic money by embracing the younger generation, especially students. The students' potential for increasing the use of electronic money is both an open attitude to change and an interest in trying new things. A survey conducted by MARS Indonesia institute in 2013 on the level of public awareness of e-money showed the following results: age 18-24 years of age of $16.7 \%$, age 25-34 years of age of 30.9\%, age 35-55 years of age of $20.2 \%$. From these results it is unfortunate because the younger generation, especially students should be able to give a big positive influence in terms Electronic money usage. Parastiti Study, et. al [3] shows the low interest of students in the use of e-money due to lack of information about the product and prefer to use cash. Meanwhile, according to Gilbert (2014) quoted from the 6.com, Indonesian consumers are still afraid to use e-money. They prefer interbank transfer and COD (Cash on Demand).

Based on the phenomenon that occurred, encouraged many researchers interested in studying factors related to the interest in e-money use. Ramadhan, et.al [4] examined the perceived use of electronic money by students and showed the results that the use of e-money interests among students if the product is easy to use, has a high level of security and a small risk, However, the perception of benefits shows results that have no significant impact on the interest in e-money. Other research by Candraditya, et.al [5] and Yogananda, et.al [6] showed different results, students are interested in using e-money if a product provides benefits or benefits for transactions that support student activities.

On the basis of the background description above, this study aims: to analyze factors that influence interest in the utilization of server-based e-money in students of the Faculty of Economics and Business, to analyze the impact of product knowledge and to assess the interest of students of Economics and Business in the use of server-based e-money.

\section{Methods}

The research method was used a quantitative method. The data was collected with distributed questionnaire to respondent. Research population is a college student at Pekalongan University Faculty of Economics and Business. The sampling method was used with criteria for purposeful sampling. Tests performed using SPSS 24 software.

Validity test and reliability test are the method of data analysis in this study. Validity tests are used to assess the feasibility of items in a variable definition list of questions (Sujarweni, 2016).

The reliability test is a measure of the stability and consistency of interviewees in responding to questions related to the structure of questions which are dimensions of a questionnaire (Sujarweni, 2016). Reliability testing of each variable is performed with Cronbach Alpha Coefficient. The data obtained will be reliable if the value of Cronbach Alpha is greater than or equal to 0.6 (Trihendradi, 2011). Normality Test assumption tests are used to determine if variables that are compared to the average are distributed normally. The decision is taken when the p-value value is greater than the significant level, then the distribution of research is normal and testing is done with a parametric statistic. If the $\mathrm{p}$-value value is smaller than the significant level, then the distribution of research is abnormal and testing should be done with non-parametric statistic. In this study, the hypothesis testing uses trajectory analysis to examine the model of a predetermined relation to find no cause. Path analysis can either directly or 
indirectly estimate the extent of the causal relationship between a number of variables and the hierarchy of the position of each variable in a series of causal paths. Direct influence means the direction of a relationship without passing another variable, while indirectly having to pass another variable. To see the magnitude of direct influence between variables using a beta coefficient or standardized regression coefficient

\section{Research and Discussion}

In the past, to test the hypothesis, product knowledge and full perception of the intention to utilize electronic money based on the server, the following results from the analysis of research data using SPSS 23.0 software.

Normality test results show a probability value of 0.200 , and this value is more significant than 0.05 . This means that the data is normally distributed. The autocorrelation test results show a probability value of 0.745 , and this value is more significant than 0.05 so that no autocorrelation occurs. Multicollinearity test results show the tolerance value for X1 (product knowledge), X2 (perceived of fullness) of 0.517 and 0.324 . These values are more significant than 0.10 , which means that there is no multicollinearity problem.

Adjust R Square value of 0.426 , which means that intention to use variable can be explained by independent variables by $42.6 \%$, while the remaining $57.4 \%$ is explained by other factors not examined. Furthermore, based on the F statistical test, it is known that the calculated $F$ value is 9,013 , with a significance value of 0.005 . This means that the significance value is less than 0.05 . So, it can be concluded that simultaneously, the independent variable has a significant influence on the dependent variable (see Table 1).

Table 1. $T$ test result

\begin{tabular}{|c|c|c|c|c|c|}
\hline \multirow[t]{2}{*}{ Model } & \multicolumn{2}{|c|}{ Unstandardized Coefficients } & \multirow{2}{*}{$\begin{array}{c}\begin{array}{c}\text { Standardized } \\
\text { Coefficients }\end{array} \\
\text { Beta } \\
\end{array}$} & \multirow[b]{2}{*}{$\mathrm{t}$} & \multirow[b]{2}{*}{ Sig. } \\
\hline & $\mathrm{B}$ & Std. Error & & & \\
\hline $1 \quad$ (Constant) & .426 & .967 & & .441 & .660 \\
\hline Product Knowledge & .204 & .055 & .194 & 3.693 & .000 \\
\hline Perceived of fullness & .722 & .104 & .459 & 6.926 & .000 \\
\hline
\end{tabular}

a. Dependent Variable: Intention To Use

The t value calculates the knowledge variable of $3.693>$ the table $t$ value is $1.9733(\mathrm{df}=179)$ for the first hypothesis. Moreover, the value of $\mathrm{t}$ is $0.000<0.05$, so that $\mathrm{H} 0$ has been rejected and $\mathrm{H} 1$ accepted. This shows that product knowledge has a positive and significant impact on the interest of university students in using electronic money based on the server. This is consistent with previous research [7] and [8].

For the second hypothesis the value $\mathrm{t}$ calculates the perception variable of $6.926>1.9733 \mathrm{t}$ table value $(\mathrm{df}=179)$. Furthermore, the value of $\mathrm{t}$ is $0.000<0.05$, so that $\mathrm{H} 0$ is rejected and $\mathrm{H} 2$ is accepted. This indicates that the perception of benefits has a positive and significant impact on the interest of students to use electronic money based on the server. This is consistent with previous investigations [9] and [6]. 


\section{Conclusion}

Due to the results of information processing using analysis tools, this study shows that product knowledge and perceived completeness have a positive and significant impact on the interest in the use of electronic money based on servers. It can be interpreted that among students, especially FEB UMPP students have an interest in using server-based electronic money, if the product has beneficial benefits while facilitating its work activities. In addition, complete product information and interesting ways of promoting make students interested in using server-based electronic money.

\section{References}

[1] Bank Indonesia, "Bank Indonesia Regulation on Electronic Money," p. 35, 2018.

[2] Bank Indonesia, "Bank Indonesia Regulation on Electronic Money," p. 35, 2"Electronic Money, Campus and Students " Financial System Stability Volunteers "," 2014. [Online]. Available: https://www.kompasiana.com/wardhanahendra/54f3df397455139f2b6c8201/uangelektronik-kampus-danmahasiswa-relawan-stabilitas-sistem-keuangan\#. [Accessed: 28-Jul-2019].

[3] A. H. Didin Elok Parastiti, Imam Mukhlis, "Analysis of The Use of Electronic Money in Students of the Faculty of Economics, State University of Malang (Case Study: Brizzi Electronic Money)," J. Ekon. and Stud. Pembang., vol. 7, no. 1, pp. 75-82, 2015.

[4] A. F. Ramadhan, A.B. Prasetyo, and L. Irviana, "Student Perception in Using E-money," J. Din. Ekon, what's going on? Business, vol. 13, pp. 1-15, 2016.

[5] H. Candraditya, "Analysis of the use of electronic money," Diponegoro J. Manag., vol. 2, pp. 1-11, 2013.

[6] A. S. Yogananda and I.M.B. Dirgantara, "The influence of benefit perception, perception of ease of use, trust and risk perception of interest to use electronic money instruments," Diponegoro J. Manag., vol. 6, no. 4, pp. 1-7, 2017.

[7] I. K. Suarjana and N. W. S. Suprapti, "The Influence of Price Perception, Product Knowledge, And Company Image on The Intention to Purchase Multi Service Services Brand Indihome," E-Jurnal Manaj. Univ. Udayana, vol. 7, no. 4, p. 1920, 2018.

[8] I. D. Kusuma and N. Untarini, "The Influence of Product Knowledge On Purchasing Intentions With Attitudes As Intervening Variables," J. Ilmu Manaj., vol. 2, pp. 1573-1583, 2014.

[9] S. Roy and I. Sinha, "Factors affecting Customers' adoption of Electronic Payment : an Empirical Analysis," vol. 19, no. 12, pp. 76-90, 2017. 